\title{
TERRITORIAL DISPARITIES BETWEEN MOUNTAINS AND LOWLANDS IN GREECE IN THE CONTEXT OF POST-2020 COHESION POLICY
}

\section{Stella Giannakopoulou ${ }^{1}$ (D) - Polychronis Kolokoussis ${ }^{2}$ (D) Apostolos Arvanitis $^{1}$}

${ }^{1}$ School of Rural and Surveying Engineering

Aristotle University of Thessaloniki

University Campus, 54124 Thessaloniki: Greece

e-mail: stellina@topo.auth.gr (corresponding author)

${ }^{2}$ Remote Sensing Laboratory, School of Rural \& Surveying Engineering

National Technical University of Athens

NTUA, Heroon Polytechniou 9, 15780, Zografou: Greece

e-mail: pol@survey.ntua.gr

\begin{abstract}
While mountain regions face territorial disparities when set against lowlands, the EU's post-2020 Cohesion Policy seeks to reduce such between regions by focusing on those that are most vulnerable. Along with regions that are otherwise remote, mountainous areas are mostly seen as in decline, and deprived of opportunities to achieve sustainable development. They face serious demographic issues connected closely with migration outflows, while they are characterised by low-quality educational services and a paucity of employment opportunities compared with circumstances in the lowlands. It against this background that the work detailed here was carried out to investigate inequalities between mountain and lowland areas of Greece. Specifically, the focus is on disparities in levels of education and unemployment, as well as population shifts. While the temporal frame comprises the period 2001-2011, the locality is the mountainous Municipal Unit of loannina, in the Region of Epirus. The findings reveal high level of inequality in all sectors of vital importance to one of the EU's poorest regions, while the further aim of the paper is to reveal the main drivers underpinning disparities in the context of post-2020 policy.
\end{abstract}

\section{Key words}

inequalities - Cohesion Policy $\bullet$ mountain regions $\bullet$ demographic changes $\bullet$ education $\bullet$ employment • Greece 


\section{Introduction}

Mountain areas cover 24\% of the world's entire land surface, and account for some $12 \%$ of the global population. In addition, millions of people depend for their living on resources present in mountains (ICIMOD, 2010; Price, Dixon, Warren, \& Macpherson, 2002; UNEP-WCMC, 2002). The global importance can be said to lie in the resources of fresh water, minerals, forests and energy that are present, as well as in high biodiversity and high diversity when it comes to local cultures (Price, Jansky, \& latsenia, 2004a,b; Nordregio, 2004; Ariza, Maselli, \& Kohler, 2013; Price, 2016). Despite this evident importance, mountains only came to the forefront in 1992, thanks to the Agenda 21 document in the context of the UN's Rio Earth Summit (UNCED, 1992). Since then, policies and legislation at national and global levels have focused on the development of mountain regions (Messerli \& Ives, 1997; Price et al., 2004a; Castelein, Dinh, Mekouar, \& Villeneuve, 2006), yet these remain among the least-developed regions, usually deemed to be lagging behind and marginalised, and facing a variety of challenges (CR 1257/1999) such as remoteness, distance from decision-making centres, depopulation, ageing, a lack of basic infrastructure and the consequences of climate change (Nordregio, 2004; Price et al., 2004a, b; EEA, 2010; Ariza et al., 2013; Panagiotopoulos \& Kaliampakos, 2019). While the EU as a whole is as much as 30\% mountainous, there are 10 of its Member States in which the comparable national figure exceeds 50\% (EEA, 2010; Euromontana, 2013; Price, 2016). EU Cohesion Policy is partly targeted at mountain regions. As 2020 approached, certain plans and forms of implementation relating to cohesion policy needed to be rearranged and revised. Previous targets as regards education, population and employment rates have not been satisfied, while post-2020 cohesion policy recognises the need for special attention to be paid to mountain regions (Gløersen, Price, Borec, Dax, \& Giordano, 2016; EUROPE 2020
Strategy; Cohesion Policy post 2020: New Cohesion Policy).

It is against this background that the present paper reports on socioeconomic inequalities pertaining between mountain areas and lowlands of Greece's Epirus Region. Specifically, the research detailed here has focused on a statistical analysis of population, education and employment, in 2001 and 2011, where the Regional Unit of loannina is concerned. Results are presented in the form of charts, tables and maps, while the Discussion reveals the main trends and driving forces behind the recent changes. Several inequalities between mountainous and lowland areas are found to exist, and are tending to increase. Mountainous municipalities are mostly depopulated, in contrast to lowlands and urban regions. It is young people that leave mountains most. Unemployment rates are higher at higher altitudes, though high rates are also met with in urban lowland areas, with the trend for the 20012011 period being upward. The highly-educated population is concentrated in lowland and urban areas.

Overall, this work has sought to inform ongoing research in mountain areas, with light shed on a mountainous part of Greece, in order that comparisons might be made with other areas of Europe facing similar challenges, and with a view to further discussion of post-2020 Cohesion Policy being engaged in.

\section{Regional inequalities in mountain regions under the 2020 Cohesion Policy}

Regional inequalities are a major topic of interest for geographical research (Kebza, Nováček, \& Popjaková, 2019). The issue relates to different levels of development from one region to another, in socioeconomic terms. Inequalities may entail income, access to services, infrastructure, education and health facilities, demographic trends, etc. Mountainous areas in Europe tend to be rural, and this is true globally - as "across the mountains 
of the world as a whole, most mountain people live in rural areas: about $70 \%$ of the total population" (Price, 2015). Their inhabitants experience high unemployment rates, a lack of services, problems with accessibility, and so on. The geographical remoteness characteristic of mountain regions is a crucial factor generating inequalities (Widuto, 2019).

The EU's post-2020 Cohesion Policy recognises the existence of regional disparities, and seeks to achieve their reduction. In addition, it puts special emphasis on most-vulnerable regions that suffer from permanent natural or demographic disadvantages - of which some are mountainous areas. The Policy provides that measures pursued post-2020 in respect of mountain regions take account of the spatial differences typical for them, the need for site-specific and small-scale programmes, and the promotion of economic activities in accordance with those already established in these areas (Gløersen et al., 2016).

Cohesion Policy 2020 seeks to achieve smart, sustainable and inclusive growth. The economy should be based on knowledge and information, be greener and more competitive and able to achieve social and territorial cohesion through high employment. Focusing on these goals, the EU arrived at several priority axes, i.e. the enhancement of education systems, the facilitation of job opportunities for young people, the provisioning of households in digital facilities, and the elimination of poverty and social exclusion (COM, 2010).

It is worth considering whether Cohesion Policy targets have been met in mountain regions specifically. Unfortunately, the relevant data from Greece and Europe are negative. In Greece, as of 2011, $80 \%$ of mountain households had no access to internet services (as compared with $53 \%$ in the country as a whole). Only $12 \%$ of the mountaindwelling population had reached the level of higher education (the figure for Greece as a whole was 29\%), and an average income of 14,293 euros a year compared with the national-average figure of 15,975 , even though expenditure on energy, for example, is far higher.

More than $98 \%$ of the country's units of administration at local level of a mountainous character are rural (source: ELSTAT, 2001 and own elaboration) and in rural areas of Greece children leave school early (girls at higher rates than boys) in 7 of the country's 13 Regions. And, as the majority of pupils entering tertiary education come from wealthy families (ELSTAT, 2011; Katsikas, 2018; Paizis \& Fotopoulos, (n.d.); Zachou, Alipranti, Bavela, Stamou, Stavropoulou, Zarotiadou, 2018), these are not likely to include people living in the mountains.

More generally, it has been established that Europe's mountainous regions resemble those in Greece in suffering from high levels of inequality in comparison with the lowland areas in general and urban regions in particular (Nordregio, 2004; Panagiotopoulos \& Kaliampakos, 2019).

The Euromontana report (of 2012) focused its consideration on seven regions (Teruel in Spain, Buskerud in Norway, Italy's Turin Mountains, Norway's Hedmark county, Sweden's Dalarna county, France's Massif Central and Italy's Valle Brembana). The report revealed how all of these regions had lost population during the most recent decades, with the young population and women being the ones to out-migrate, mainly for education and work. However, interregional disparities exist; more remote areas are losing population, while some urban or tourist areas are gaining people. The 2004 Nordregio report in turn revealed several characteristics of mountain regions in 29 European countries. Higher concentrations of elderly population are found in the mountains of the Balkans and France, as well as those of the UK, Ireland, the Nordic countries and Portugal, as well as some parts of the Alps. Between 1991 and 2001, far-reaching depopulation took place in the mountains of Corsica, Sicily and Italy's central Apennines. Depopulation rates were higher in mountains than in lowlands in all of the countries studied. 
At a more local level, certain inequalities exist in several of Europe's mountainous areas. Bearing in mind the purpose of work detailed in this paper, relevant literature was sought for certain paradigms indicative of inequalities, with the focus being on the three key subjects of demography, education and employment. These are summarised in what follows.

The Apuseni Mountains of Romania have seen rapid deterioration of the demographic situation, with ageing and economic dependency across the region, increasing vulnerability, and the level of dependence on central areas. However, internal disparities do occur, with the most mountainous areas (> $800 \mathrm{~m}$ ) facing highest rates of aging and out-migration (Drăgan, 2010). In the mountains of Georgia (Oni municipality) depopulation and ageing prevail. Between 1989 and 2014, the most-elevated settlements lost their entire population, while middle-altitude settlements lost almost 59\% and the zone at the lowest level almost $49 \%$. Remaining population concentrates in the lowlands (Kohler, Elizbarashvili, Meladze, Svanadze, \& Meessen, 2017). Depopulation is also taking place in the mountainous Spanish region of Aragon. Between 1860 and 2000 that region lost $56 \%$ of its population (Collantes \& Pinilla, 2004; Lung, 2019). Despite the general in-migration in the Alps, high population losses are to be noted in the eastern part of the range on Austrian territory (Čede, Deissl, Löffler, \& Steinicke, 2018).

In the Carpathian region, there has been a high rate of out migration generally since the 19th century. This ensures that even relatively high birth rates fail to generate an increase in population. The two countries showing the highest rates of out migration (in terms of the NUTS3 regional level) are Romania and Austria. In addition, some regions in the Carpathians (especially of Poland and Slovakia) show the highest rates of unemployment, along with very low activity rates (i.e. an inactive working-age population). Youth unemployment is high, rising to $40 \%$ in some areas. The majority of those affected by unemployment have primary education only, with the attainments lower on average among females than males. There are marked differences between urban and rural areas in terms of levels of education. The Carpathian Mountains in Poland, Ukraine and Slovakia were mainly depopulated after the collapse of the Soviet Union, while demographic problems similar to those in the Romanian Carpathians afflict central areas of the Caucasus Mountains, where depopulation, a decline in birthrates and ageing all prevail (with $37 \%$ of the population over 65 years old). Depopulation is also typical for the mountains of North Macedonia, where the rural population has decreased by $50 \%$ since the post-War period. A similar situation applies in the mountains of Bulgaria, where demographic risk phenomena are present (Mladenov and Ilieva, 2012; Lung, 2019).

Certain regions in central and northern Europe show evidence of population stability and, indeed, growth. This is true of the French Alps, Murcia (Spain), Slovenia, Switzerland, western Austria, parts of Germany and Italy (Nordregio, 2004; Bauer \& Fassmann, 2010). However, as has been noted, the Alpine regions of Austria has been experiencing high rates of immigration, especially of an international nature, since 2002 (Dax \& Machold, 2019). The Alps as a whole are not regarded as an out-migration region (Löffler, Beismann, Walder, \& Steinicke, 2014) though regional disparities exist. In-migration is also evident in the eastern part of the Italian Alps, and in the Julian Alps of Slovenia (Čede at al., 2018).

Expressed in terms of rates of employment, a high diversity of economic activities characterises Europe's mountain areas. In Switzerland, Norway, the Polish Carpathians, Bulgaria, the French Pyrenees, the Azores and Finland, the role played by the primary sector is greater in the mountains than in the lowlands. This despite the fact that the tertiary sector accounts for the greatest share of employment in all countries (Nordregio, 2004).

Mountain areas face a variety of social and economic challenges, as the above facts 
make clear. Being forced to respond to such challenges, mountain regions are considered capable of innovation and creativity and, thus of inspiring solutions. The 2020 agenda provided that mountains might play an important role as welcoming areas, given their potential to sustain life of greater quality, with a new perspective on life on offer to all of those fed up with living in the city (Euromontana, 2013). Within such a framework, post-2020 cohesion policy would be able to play a decisive role as it targets re-evaluation of the relationship between mountain and lowland regions, with a view to the future for mountain regions being a more prosperous one.

\section{Methodology and data}

The objective of the work underpinning this article has been a spatial analysis of differences between mountain regions and lowlands of a representative study area, in respect of the three main axes represented by demographic changes, educational level and employment. The aim has been to attest to certain spatial inequalities, to point to the main disparities connected with mountain regions, to reveal ongoing trends and future prospects, and to establish conclusions within the context of ongoing research into the future of mountain areas of Europe, in line with post-2020 Cohesion Policy.

The first part of the aforementioned work entailed the collection and elaborate analysis of relevant literature regarding the characteristics and importance of mountain regions, the 2020 Cohesion Policy, the EU archives on the post-2020 policy discussion, and case studies relating to Europe's mountain areas that focus in on their inequalities in comparison to adjacent lowlands.

In the event, the extensive bibliographic analysis (already outlined in the previous section) revealed the existence of major inequalities, notwithstanding the initial targets of the 2020 Cohesion Policy. As the post-2020 period is now approached, certain inequalities are seen to widening, while also being highly concentrated spatially. Further, the levels appear to be even higher where mountainous areas are concerned. Several studies show how mountain regions are less developed in general than the lowlands nearby, and are vulnerable to further declines in the near future. Literature analysis makes it clear that mountain regions lag behind in the sectors of demography, education and employment first and foremost - hence the choice of these as this study's main driving axes. These indicators (two social and one economic) offer key insight into a region's rate of development, and are of central importance where Cohesion Policy is concerned.

The second part of the work contributing to this paper concentrated on the collection and analysis of data regarding the study area, with statistical data on population, education and employment from the ELSTAT censuses of 2001 and 2011 investigated in respect of the scale represented by the Local Administrative Unit (LAU). The population referred to in the analysis is the permanent one'. Municipalities (2001) and Municipal Units (2011) represent the spatial level of statistical analysis used (at LAU 1). It was determined that data analysis would be engaged in for the two most recent ELSAT consensuses in order that the study area's main trends and future prospects might be identified. Primary data collected from ELSTAT was thus processed, with comparative analysis of data pursued for each of the three indicators, and presentation taking the form of charts and tables. The statistical data were processed and analysed using spreadsheet software (Microsoft Excel and LibreOffice $\mathrm{Ca} / \mathrm{c}$ ), as well as that relating to opensource GIS (QGIS). Several findings from the analysis were mapped, with polygon colourscaling and graphs as main components. The backgrounds are in turn selected to refer to the shaded relief of the area (produced using GDEM V2.0), so that the viewer might appreciate readily the mountainous relief

\footnotetext{
1 Permanent population: population whose permanent house / living is in the corresponding administrative unit (source: ELSTAT).
} 
of areas included within the polygons. The latter used in mapping were defined in terms of the official boundaries of municipalities, which differ in the circumstances of 2001 and 2011 (with 41 the municipalities of 2001 contrasting with the 8 municipal units of 2011). This fact complicated the comparative interpretation of the results. Use is made of the Hellenic Geodetic Reference System 1987 (HGRS87).

The third part of the study saw findings for the study area discussed, and compared with relevant literature. Similarities and differences between the study area and several further regions of Europe also gain discussion. Furthermore, the findings from the study offered an indication of certain key factors needing to be considered as main directions for research to focus on in the context of post-2020 policy for mountain regions.

\section{Mountainous areas of Greece}

Greece is roughly 75\% mountainous, though the $77.8 \%$ reported in the Nordregio report (2004) may be set against the $72 \%$ figure offered by the EEA (2010). As can be inferred, there is no single and/or universal or panEuropean definition of mountain areas (Price et al. 2004b; Ruffini, Streifeneder, \& Eiselt, 2006). While "mountains" are basically areas capable of being defined geographically, "mountain areas" are actually the sum total of all those lowest-tier units of administration that encompass "mountains" and are in that sense mountain units of administration). Some clarification may be offered where a decision is taken to regard a mountain municipality as entirely mountainous, or only partially so. There is in fact an incredible amount of literature on terrain analysis and the classification of mountains and mountainous areas by reference to a variety of morphological parameters. In their work, Darra, Kavouras, and Tzelepis (2003 and 2010), describe the former manual characterisation of mountainous areas in Greece (as a basis for the implementation of Directives 85/148/EEC and $75 / 268 /$ EEC), as well as the new digital (more-objective) characterisation of mountainous LAUs based on 48 slope/elevation combinations, a weighted relief index and a ternary diagram. This methodology has been adopted by ELSTAT, which has classed all units of administration as mountainous, semi-mountainous or lowland.

Here it is statistical data after the ELSTAT characterisation of units of administration that are analysed. Moreover, this takes place in line with the key determinant altitudes derived from the above methodology, i.e. below $600 \mathrm{~m}, 600 \mathrm{~m}-800 \mathrm{~m}$ and above $800 \mathrm{~m}$.

Furthermore, ELSTAT (2001) categorises all units as either Urban or Rural. However, in the study area context all mountainous Municipal Units are Rural, except the MU of loannina, the MU of Konitsas and the MU of Metsovou (which have been termed Urban). This has also been taken into consideration in the study, with the relevant ELSTAT data utilised.

\section{Selection of the study area}

In accordance with a law adopted in 2010, there is a difference between the administrative divisions pertaining in 2001 and 2011. As of 2001, Greece was divided into 900 Municipalities and 133 Communities (further subdivided into smaller municipal and community units). As many as $61.6 \%$ of these were assigned to the mountainous and semi-mountainous categories, accounting for $71.3 \%$ of the area in total (ELSTAT, 2001). However, in 2010, Law 3852/2010 provided for a reorganisation of Greece into 325 Municipalities and no Communities (ELSTAT, 2011). This was achieved through the combining of former Municipalities (further subdivided into smaller municipal units), with Communities no longer taken account of. On a broader scale, Greece is divided into 13 Regions, of which each has several Regional Units (RUs). In this study, the selected study area was the Region of Epirus, with more of a focus on its largest RU - the Regional Unit of loannina (NUTS3). The exact administrative division of the study area is as presented in Table 1. 
loannina, as capital of loannina RU, has 65,575 residents. Epirus is in NW Greece, covering a total area of $9203 \mathrm{~km}^{2}$ and consisting of the RUs of loannina, Arta, Preveza and Thesprotia. The RU of loannina accounts for more than half of Epirus Region, with an area of $4999 \mathrm{~km}^{2}$ (Fig. 1). Where the Local Administrative Unit (LAU) scale is concerned, the RU of loannina consisted of 41 Municipalities and Communities after 2001, but these were merged to become 8 new Municipalities in 2011 (Tab. 1). The latest statistical data from ELSTAT were collected in 2001 and 2011, hence follow the merging of LAUs. This complicates comparisons between the two most recent statistical data periods, though this study (on the LAU scale) seeks to achieve comparison and analysis, in order that useful conclusions might be drawn regarding disparities between mountains and lowlands within the study area, and in Greece more generally.

Epirus was chosen as a case-study area for a variety of reasons. It is one of Greece's most mountainous regions (with $74 \%$ in this category), and also one of its poorest and less-developed. Beyond that, the Epirus region is among the poorest anywhere in the EU. Specifically, it is among the European Union's 20 poorest Regions in terms of per-capita GDP (Eurostat, 2019), with this meaning additional burdens where local development is concerned. This all ensures that there is an important field here for the study of social and economic disparities at local level. As a mountainous region, Epirus is among the EU's Less-Favoured Areas (LFAs), as designated as long ago as in 1975 (by virtue of Directive 75/268 EEC), becoming one of the Areas with Natural Constraints (ANC) as redefined later (Terres, Toth, Wania, Hagyo, Koeble, \& Nisini, 2016). These areas feature a variety of challenges due to their natural environment. Among these are significantly higher production costs, shorter growing seasons due to altitude and climatic conditions, and a lack of possibility of machinery being used due to steep slopes that demand very expensive equipment. All of the above circumstances led the EU to provide for a certain compensation of farmers living in these areas so that they might be better supported. Mountain regions also face the risk of depopulation and lack certain basic infrastructure in a manner that justifies their description as facing permanent handicaps due to their natural terrain (CR 1257/1999). Less-Favoured Areas are very often marginalised, both socially and economically. Hence, without support, they will experience further depopulation, an abandonment of farming or other activities, and higher rates of unemployment. These will, in turn, lead to the emergence of a variety of natural and cultural dangers such as land

Table 1. Reform of the administrative division of the Epirus Region as of 2011 and 2001 (juxtaposition)

\begin{tabular}{|c|c|c|c|c|c|c|c|c|}
\hline \multicolumn{9}{|c|}{2011} \\
\hline Municipalities & Metsovou & Pogoniou & Konitsas & Zitsas & Dodonis & loanniton & Zagoriou & $\begin{array}{l}\text { North } \\
\text { Tzoumerkon }\end{array}$ \\
\hline \multicolumn{9}{|c|}{2001} \\
\hline Municipalities & $\begin{array}{l}\text { Egnatias, } \\
\text { Metsovou }\end{array}$ & $\begin{array}{l}\text { Ano } \\
\text { Kalama, } \\
\text { Ano } \\
\text { Pogoniou, } \\
\text { Delvinak- } \\
\text { iou, } \\
\text { Kalpakiou }\end{array}$ & $\begin{array}{l}\text { Konitsas } \\
\text { Mastoro- } \\
\text { chorion }\end{array}$ & $\begin{array}{l}\text { Ekalis, } \\
\text { Evru- } \\
\text { menon, } \\
\text { Zitsas, } \\
\text { Molosson } \\
\text { Pasaronos }\end{array}$ & $\begin{array}{l}\text { Ag. } \\
\text { Dimitriou, } \\
\text { Dodonis, } \\
\text { Dervi- } \\
\text { zianon, } \\
\text { Sellon }\end{array}$ & $\begin{array}{l}\text { Ioanniton, } \\
\text { Anatolis, } \\
\text { Bizaniou, } \\
\text { Pamvoti- } \\
\text { dos, } \\
\text { Peramatos }\end{array}$ & $\begin{array}{l}\text { East } \\
\text { Zagoriou, } \\
\text { Central } \\
\text { Zagoriou, } \\
\text { Timfis }\end{array}$ & $\begin{array}{l}\text { Katsa- } \\
\text { nochorion, } \\
\text { Pramanton, } \\
\text { Tzoumerkon }\end{array}$ \\
\hline Communities & Mileas & $\begin{array}{l}\text { Lavdanis, } \\
\text { Pogonianis }\end{array}$ & $\begin{array}{l}\text { Aetomil- } \\
\text { itsas } \\
\text { Distratou } \\
\text { Fourkas }\end{array}$ & & & $\begin{array}{l}\text { Nisou loan- } \\
\text { ninon }\end{array}$ & $\begin{array}{l}\text { Vovousas, } \\
\text { Papigou }\end{array}$ & $\begin{array}{l}\text { Vathipedou, } \\
\text { Kalariton, } \\
\text { Sirakou, } \\
\text { Matsoukiou }\end{array}$ \\
\hline
\end{tabular}




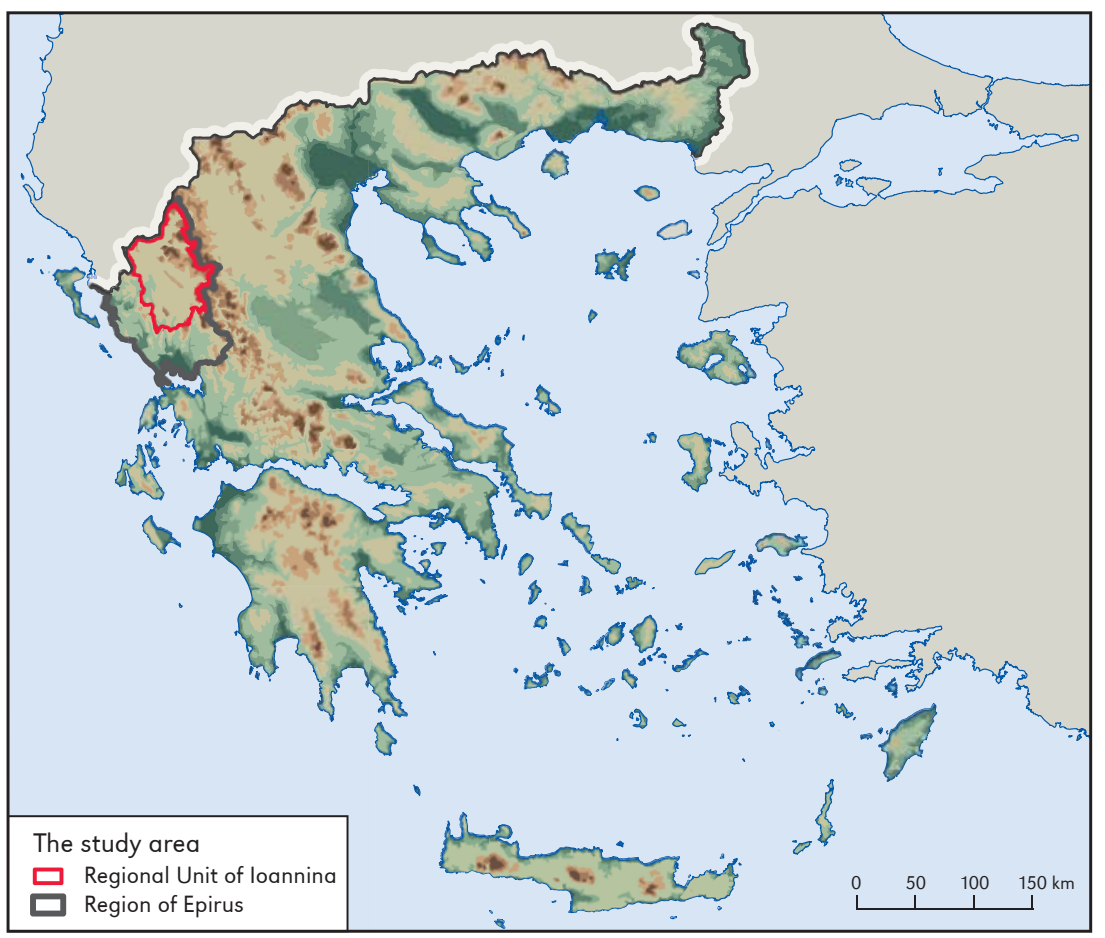

Figure 1. Epirus Region and the Regional Unit of loannina on the map of Greece

degradation, soil erosion, forest fires, social decline, the abandonment of local traditions, and so on. The danger is thus of a vicious circle tending to embed areas involved in further poverty and underdevelopment. The need for such areas to be protected and supported is evident. Mountainous areas have a place in the current policy agenda of their own right, due to a global significance that is further documented elsewhere in this paper. However, the establishment of a certain policy presupposes understanding of these areas' special characteristics.

The Region of Epirus epitomises LessFavoured and handicapped areas of the above kinds, therefore constituting one of the most suitable places in which to study socioeconomic inequalities at local level, especially with the upcoming EU policy period in view. Analysis of the kind envisaged was expected to provide for robust conclusions as regards the parameters that are main drivers of poverty and depopulation in Epirus. In addition, knowledge for ongoing research into Less-Favoured Areas was anticipated. In any case, Epirus has been among the main fields of systematic research for the authors over the last decade.

A very brief description of the Region of Epirus can be offered thanks to CORINE Land Cover 2000 data (the closest to the 2001 ELSTAT statistical data). 23.4\% of all the land here is agricultural, while $74.6 \%$ is under forest and just $0.4 \%$ is built-up. From this, $12.7 \%$ is urban and $68.6 \%$ rural. There are 32 Natura 2000 sites in Epirus, accounting for nearly half (47\%) of the Region. There are 82 settlements in the "Traditional" category. This Region's main range is the Pindos Mountains ("the backbone of Greece"), which here forms the eastern boundary. Epirus has a long and important history that dates back to the Palaeolithic era (data from www.epirus. gov.gr). 


\section{Results and Discussion}

This paper has been developed on the basis of an examination of inequalities between mountain and lowland regions within the same Regional Unit. The axes considered involved population, education and employment. The analysis and results gain presentation by way of charts, tables and maps.

\section{Population inequalities between lowland and mountain parts of the Regional Unit of loannina}

While the Greek mountains were massively inhabited until the 14th-15th centuries, they embarked upon a path of development decline from the 1950s onwards. While geographical isolation functioned as a safety net for mountain cultures, the absence of integrative development policy resulted in depopulation, limited educational attainments among those continuing to inhabit the area, a lack of basic facilities and services, etc., (Dimitriadis, 1997; Matsouka \& Adamakopoulos, 2008; Giannakopoulou, 2012). Hence the aforementioned steady decline in population in Greece's mountainous areas, ongoing since the 1940s (Tab. 2). The mostsevere losses were noted in the 1940-1950 and 1960-1970 periods. Overall, the mountain regions lost half or more of their people (Basiouka, 2011). The outmigration involved was provoked by World War II, Greece's Civil War and massive urbanisation, with people choosing either foreign destinations or the urban lowlands. In the case of Epirus Region specifically, the loss was of $42 \%$ of the total de facto $^{2}$ mountainous population in the 1940-2001 period. In fact the RU of loannina lost as many as $52 \%$ of its people, while the RUs of Arta, Preveza and Thesprotia witnessed respective declines of 31,17 and $54 \%$ (Basiouka, 2011).

Analysis of 2001 population data reveals that more than half (55\%) of the total population of loannina RU is concentrated at altitudes of no more than $500 \mathrm{~m}$. Almost 27\% live between $500 \mathrm{~m}$ and $600 \mathrm{~m}$, while just $18 \%$ of people are in settlements located more than $600 \mathrm{~m}$ above sea level. Among the latter are the $9.5 \%$ that reside above $800 \mathrm{~m}$, with just $4 \%$ among these resident at altitudes in excess of 1000 m (Fig. 2B). Beyond that, almost half (46.9\%) of the total population of the RU of loannina is concentrated in the Municipality of loanniton, while the rest is scattered among 28 Municipalities and 13 Communities (Fig. 3). It is worth mentioning that a relatively high percentage (2.5\%) of total population lives in the M. of Metsovou, which is at $1150 \mathrm{~m}$ a.s.l. This reflects the status of the town of Metsovou (this Municipality is Urban, according to ELSTAT, 2001), which has a long history, was never abandoned by its inhabitants, and has in fact been a constant presence for more than six centuries. The town supports a variety of services (i.e. schools, a small hospital, public services, etc.) and satisfying employment opportunities. In addition, Metsovou attracts almost 200,000 visitors

Table 2. Population shifts between 1941 and 2011, in Greece

\begin{tabular}{|l|c|c|c|c|c|c|c|c|}
\hline & \multirow{2}{*}{$\begin{array}{c}\text { Area } \\
{[\%]}\end{array}$} & \multicolumn{7}{|c|}{ Population shifts [\%] } \\
\cline { 3 - 10 } & & $1941-1950$ & $1951-1960$ & $1961-1970$ & $1971-1980$ & $1981-1990$ & $1991-2000$ & $2001-2011$ \\
\hline Lowlands & 29 & 10 & 14 & 12 & 14 & 6 & 8 & 2 \\
Semi-mountainous & 29 & 0 & 7 & -1 & 11 & 7 & 7 & 0 \\
\hline Mountainous & 42 & -16 & -2 & -21 & -5 & -1 & 1 & -18 \\
\hline
\end{tabular}

\footnotetext{
2 De facto population: population present in the corresponding administrative unit, on the day of the Census (source: ELSTAT).
} 


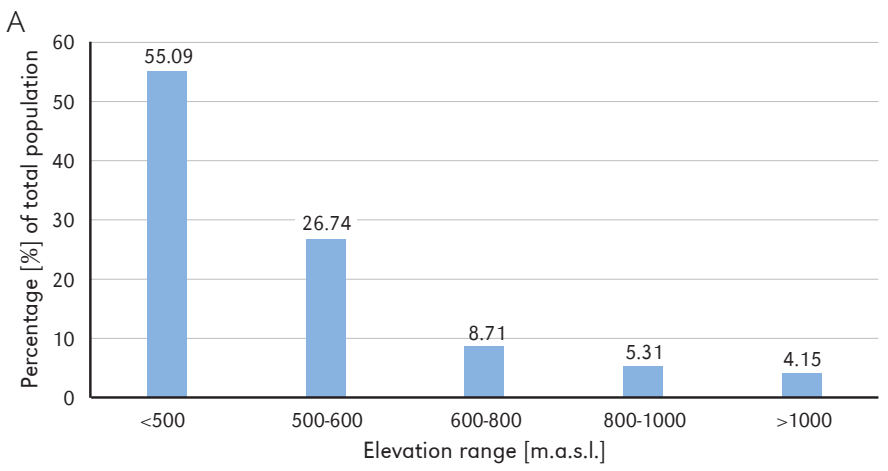

B

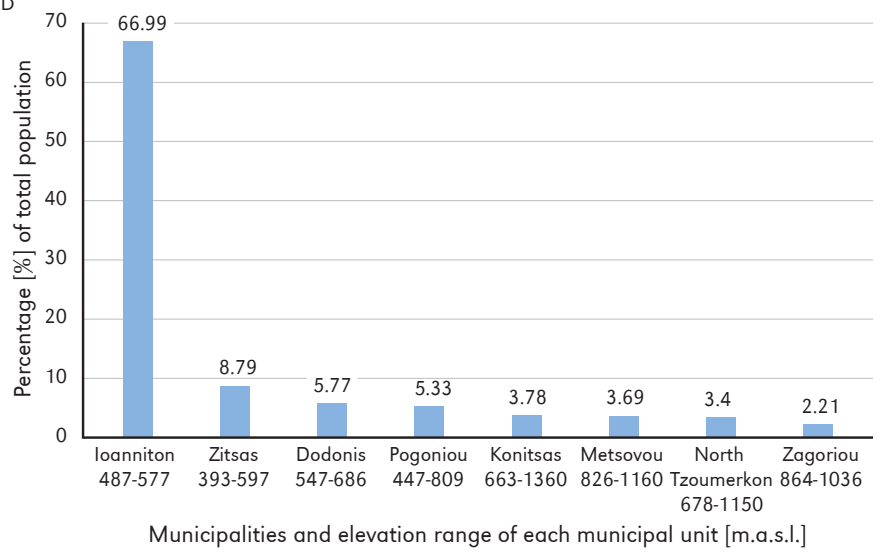

Figure 2. Percentages of the overall population by altitude, as of 2001 (A) and 2011 (B)

annually, and is located just 20 minutes by car from the urban center of loannina.

In 2011, $67 \%$ of the total population was (again) concentrated in the Municipality of loanniton. Remaining people were scattered among 7 Municipalities (Fig. 2B). loanniton's share was higher than in 2001 (when the figure was 64\%) (Tab. 1, Fig. 3). In contrast, the share accounted for by the MU of Metsovou was down to $3.69 \%$, from $4.45 \%$ in 2001 . While this is a minor reduction, the relevance is that Metsovou is one of the last remaining settlements located above $1000 \mathrm{~m}$ to have a population anywhere near as large as this. It remains to be seen whether the trend towards outmigration will prove a firm one.

As of 2001, the younger population (aged 15-54) was mostly concentrated at altitudes of up to $600 \mathrm{~m}$. The highest percentages characterised the Municipalities of loanniton (63\%), Anatolis (61.5\%), Peramatos (64\%) and Pasaronos (54\%), which are either urban (loanniton and Anatolis are Urban and Lowland - ELSTAT) or very close to urban areas (M. Peramatos is adjacent to that of loanniton). Perama, its centre lies just $3 \mathrm{~km}$ away from the city of loannina. M. Pasaronos is also adjacent to M. loanniton, with its centre $7 \mathrm{~km}$ from loannina city). These regions also reported the lowest percentages for the population over 55. At the same time, Municipalities at higher altitudes had higher percentages of people who were elderly. The highest values of all were noted for the Municipalities of Tzoumerkon (79\%), Vathipedou (71\%), Mastorochorion (56.5\%) and Vovousas (50\%). All of these areas are rural and mountainous (over 800 m) (Fig. 4 - A and B). 


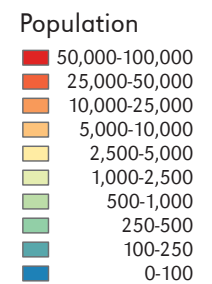

Gender composition Share of

Men Women

Municipalities

and Communities:

1. Aetomilitsas

2. Ag. Dimitrio

3. Anatolis

4. Ano Kalama

5. Ano Pogoniou

6. C. Zagoriou

7. Delvinakiou

8. Dervizianon

9. Distratou

10. Dodonis

11. E. Zagorio

12. Egnatias

13. Ekalis

14. Evrumeno

15. Fourkas

16. Ioanniton

18. Kalpakiou

19. Katsanochorion

20. Konitsas

21. Lavdanis

22. Mastorochorion

23. Matsoukiou

24. Metsovou
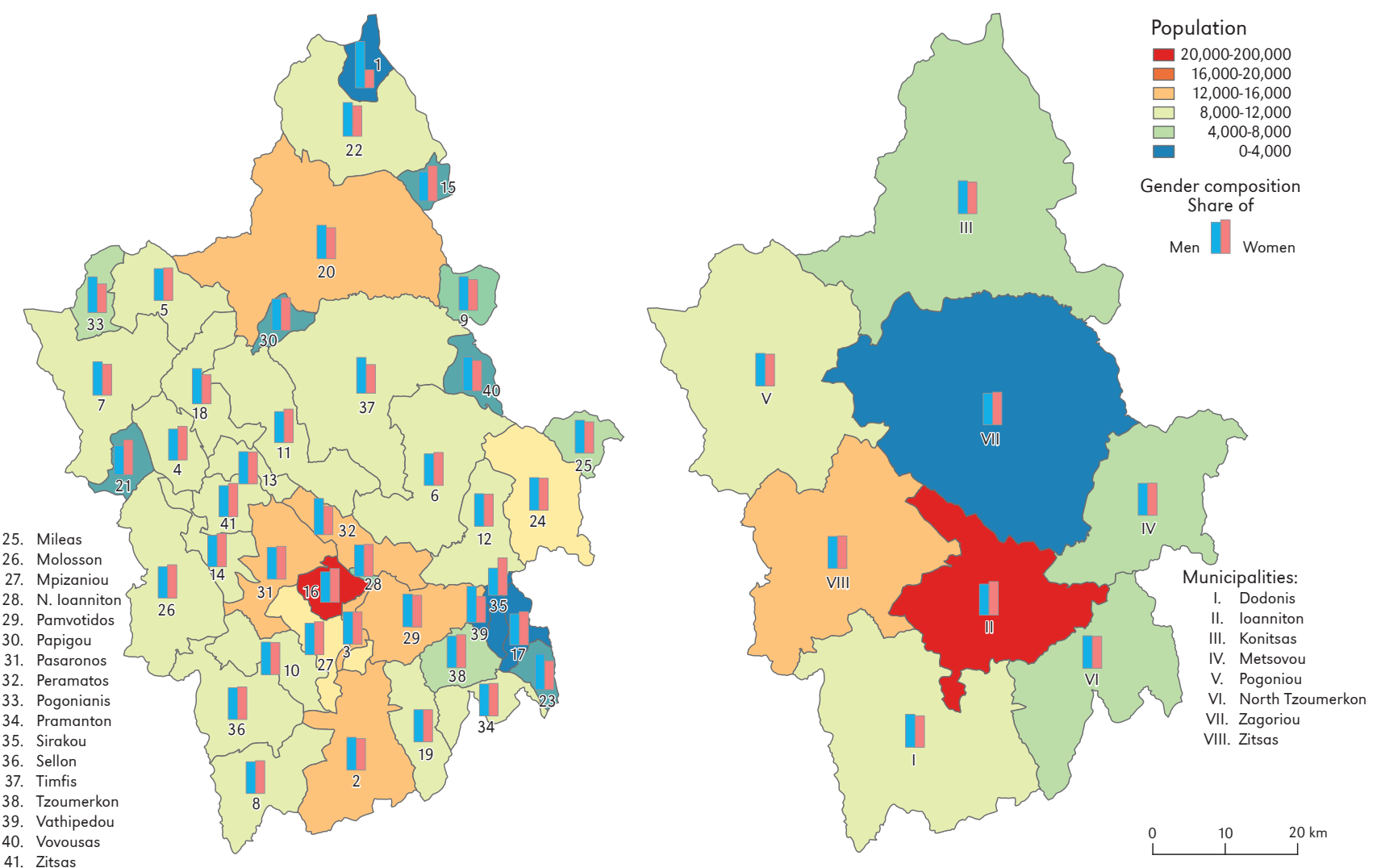

Figure 3. Population by municipality as of 2001 (A) and 2011 (B) in numbers 


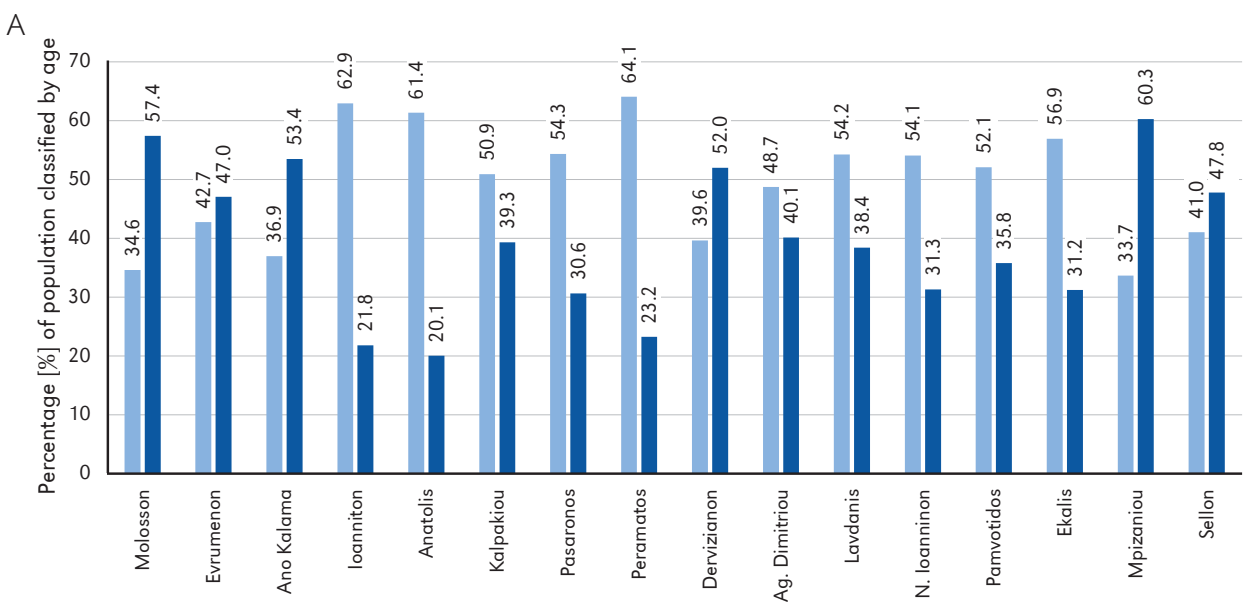

Municipal Units with elevation range between 393 and 597 [m.a.s.I.]

B

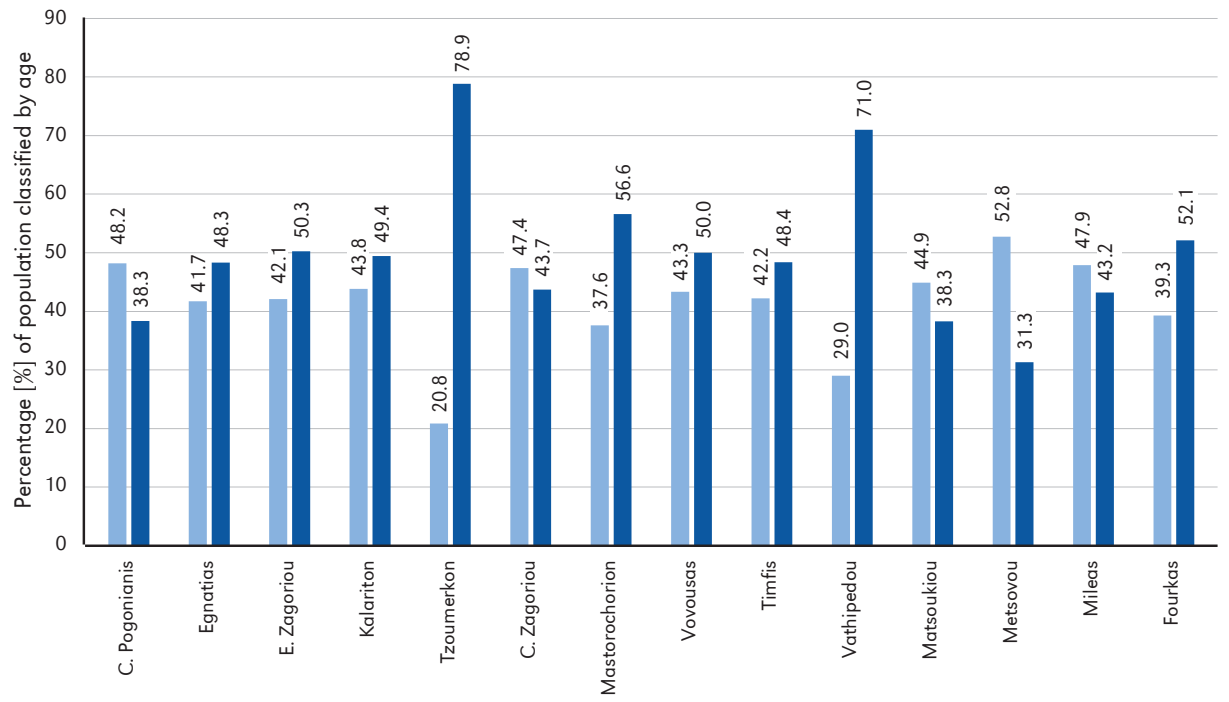

Municipal Units with elevation range between 809 and 1430 [m.a.s.I.]

Age 15-54

Age $>55$

Figure 4. Percentages of the population aged 15-54, or over 55, at low altitudes (A) and at high altitudes (B)

By 2011, the younger population (aged 10-50) was mostly concentrated in the lowland municipalities of loannina (75\%) and Zitsas (8\%), with the vast majority living near the city of loannina. At the same time, the most mountainous municipalities hold very low percentages of younger people with Konitsas on 2.9\%, North Tzoumerkon on 2.3\% and Zagoriou on $1.6 \%$.
The results confirmed the depopulation of past decades and the ageing of the population remaining in mountain regions. Metsovou is an exception, with a young population in which more than $50 \%$ of people are aged 15-54, while $30 \%$ are 55 and over. It emerged that, as of 2011, the RU of loannina had more of the elderly (over-60) population and fewer people who were young (aged 30-59), in comparison with the national average (Fig. 5). 


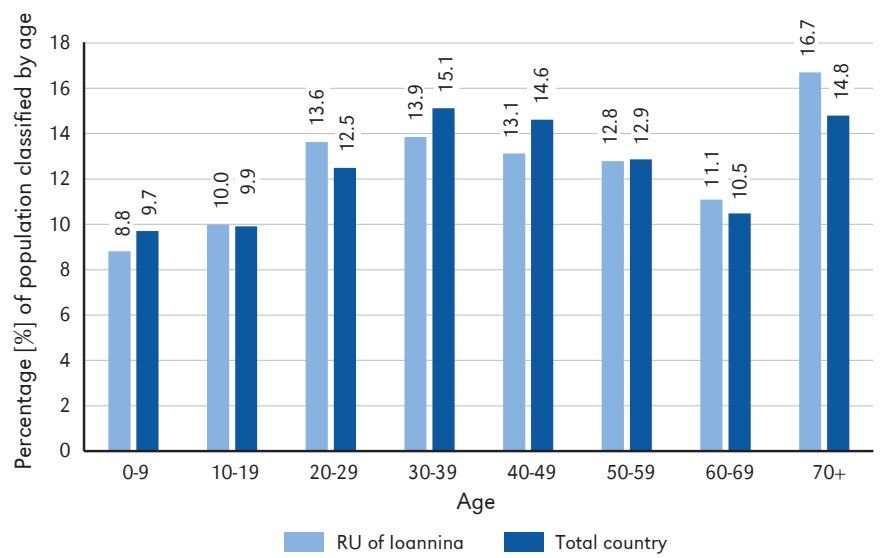

Figure 5. Comparison of the breakdown of the population by age group in the Regional Unit of loannina and in Greece as a whole

Low percentages of people of productive age $(30-60)$ reveal a certain population mobility from loannina, either to Greece's urban centres or abroad. However, comparative analysis relating to gender and population (see also Fig. 3) failed to reveal significant differences among municipalities. There was an overall equal distribution of the two genders, in each municipality, as of 2001 and 2011.

\section{Educational inequalities between lowland and mountain regions of the Regional Unit of loannina}

As of 2001, higher percentage figures for the better-educated population were concentrated in municipalities at altitudes up to $600 \mathrm{~m}$. Among those, the highest percentages were noted for the municipalities of loanniton (19.4\%), Anatolis (12.2\%) and Bizaniou (12.2\%) (which is rural and semi-mountainous - ELSTAT). Above $800 \mathrm{~m}$, all but three areas noted percentages of the population with higher education in the 1.7-8\% range (Fig. 6A, Fig. 7).

Three regions at high altitude (> $800 \mathrm{~m})$ were found to have high percentages for the highly-educated population, i.e. the municipalities of C. Zagori (11\%), Papigou (15.9\%) and Aetomilitsa (14\%). While the absolute numbers of such people are small, the results reveal an interesting phenomenon documentable in certain mountain regions in recent years. People may leave cities behind for a variety of reasons, to make a life re-start, choosing to settle in mountains. These are the so-called "amenity migrants" (Moss, 2006, 2008) known most commonly from the Alps and the Rockies. Although such people are not yet part of a major trend in Greece, many have played a decisive role in arresting depopulation in several areas at least. Those involved are usually employed in the tourism sector, they reuse abandoned buildings and they are usually young and well-educated. It is this population reflected in the study's results and the three municipalities involved are well-known tourist destinations.

Analysis of data on the illiterate population as of 2001 reveals higher percentages in the municipalities of Tzoumerkon (34.4\%), Kalariton (33.3\%), Sellon (30\%), Pramanton (29.9\%), Matsoukiou (29\%) and Egnatias (28\%) - all rural areas, above $680 \mathrm{~m}$, and in fact including some of the RU's most mountainous settlements. The lowest percentages for the illiterate population were in turn to be met with in the lowland, urban municipalities of loanniton (5.5\%) and Anatolis (9.5\%). C. Zagori (13\%), Papigou (4\%) 


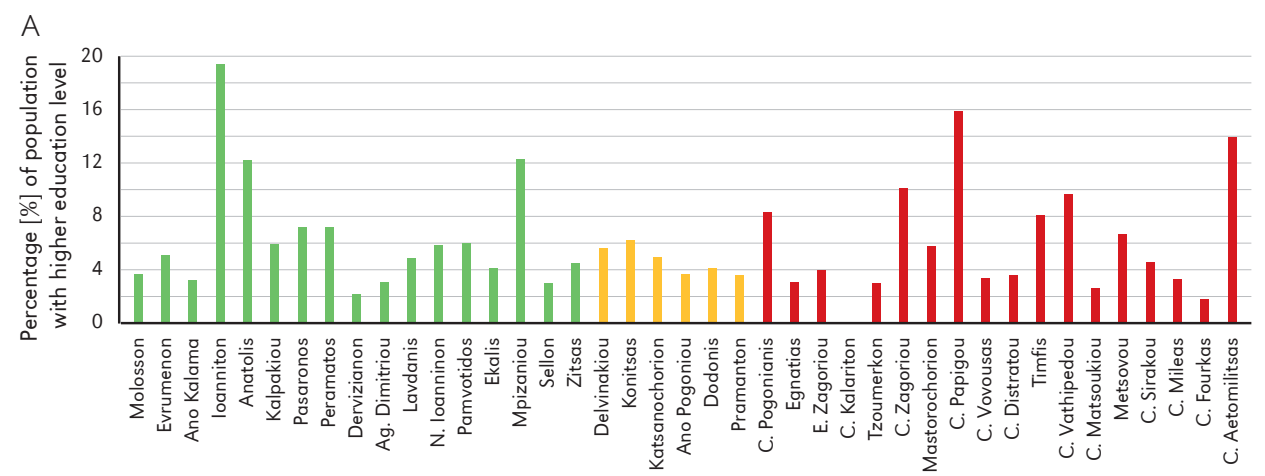

B

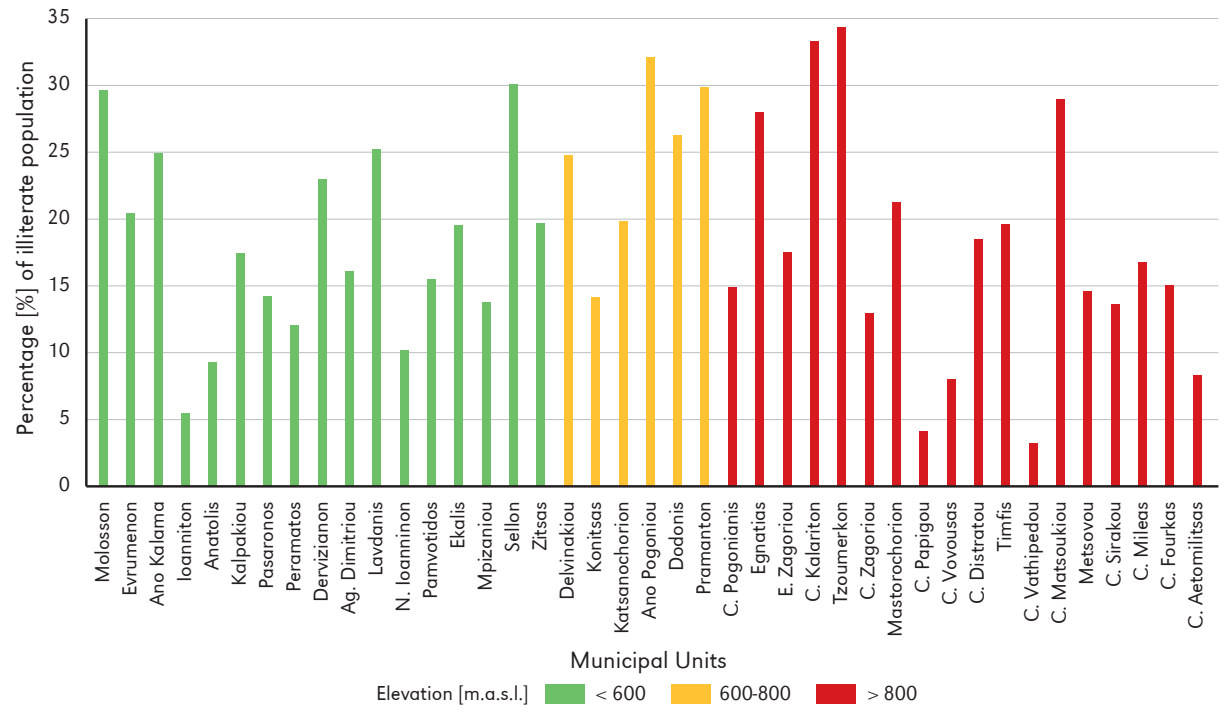

C

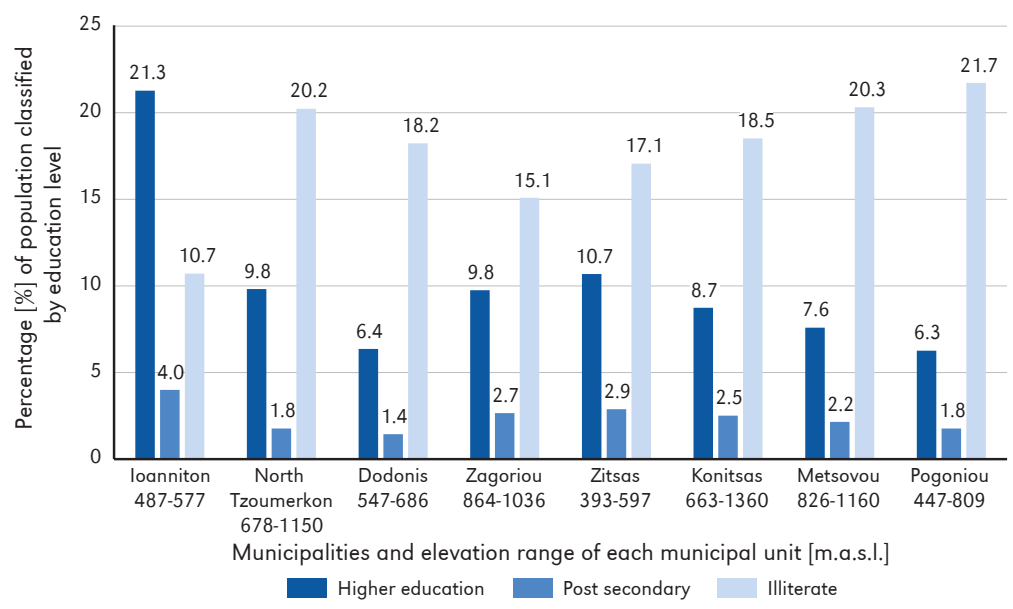

Figure 6. Percentages of the population with higher education as of 2001 (A), percentages of the population not literate as of 2001 (B) and percentage breakdown of the population by level of education as of 2011 (C) 
and Aetomilitsas (8\%) also featured low percentage figures for the illiterate population (Fig. 6A, Fig. 7A).

In 2011, higher percentages of the population with attainments in higher education were concentrated in the Municipality of loanniton (17\%) and Zitsas (10.7\%). Both municipalities include areas at altitudes in the 393-597 $\mathrm{m}$ range. Higher altitudes (> $800 \mathrm{~m}$ ) hold an average $9 \%$ of the population with higher education (M. of North Tzoumerkon, Zagoriou, Konitsas and Metsovou). At the same time, the highest percentages of illiterate people are concentrated in the most mountainous areas, and specifically in M. Ano Pogoniou (21.7\%), M. Metsovou (20.3\%) and M. North Tzoumerkon (20.2\%). The lowest percentage is the $10.7 \%$ met with in M. loanniton. Similarly, higher percentages of population with postsecondary education are concentrated in $\mathrm{M}$. loanniton (4\%) and M. Zitsas (2.9\%), while all other municipalities have lower percentages (Fig. 6C, Fig. 7B).

Analysis of gender data reveals only minor differences. In 2011, almost all municipalities featured higher percentages of men with higher education than women. At the same time, a higher percentage of women than men are illiterate in almost all municipalities. These results reflect beliefs and lifestyles from the past that gave schoolattendance privileges to boys, while assuming a role for girls in domestic service above all.

\section{Employment inequalities between lowland and mountain regions of the loannina Regional Unit}

As of 2001, average unemployment rates were in the $10-14 \%$ range, albeit with $17 \%$, $19 \%$ or even higher levels reached in some municipalities. Worst cases were Timfi (19\%), Vathipedou (40\%), Kalariton (28\%) and Sirakou (48\%) (Fig. 8A), though it is typical for these to represent small numbers of people in absolute terms. In any case, the results make it clear that unemployment is mainly concentrated in the most mountainous regions (as all of the localities referred to are above $800 \mathrm{~m}$ ). M. loanniton on 13\% unemployment had a figure seen as relatively high when set against the average for the Region (Fig. 9A). That finding reflects the high levels of unemployment to be met with in urban areas. More than half of the unemployed are "new" (i.e. "people who search for a job for the first time"). On average, rates for such new unemployment are in the $40-100 \%$ range (where this is noted as a percentage of total unemployment) (Fig. 8B).

Comparative analysis of unemployment rates among men and women shows higher rates for the former in almost all municipalities, with the difference only becoming more acute at higher altitudes. Greater disparities between the sexes characterised the municipalities of Ano Kalama (70\% - 30\%), Ano Pogoniou (61\% - 39\%), Mastorochorion (75\% - 25\%), Metsovou (64\% - 35.5\%) and Tzoumerkon (87.5\% - 12.5\%). rates of "new" unemployment were likewise found to be higher among men than women. These inequalities again proved even wider at higher altitudes (Fig. 10A).

As of 2011, the average rate of unemployment was between 16 and 20\%. Increased unemployment reflected the economic crisis in Greece persisting in the whole period from 2009 onwards. As of 2011, the RU of loannina saw the vast majority (72\%) of its employed population concentrated in $\mathrm{M}$. Ioanniton. $8.5 \%$ was noted for M. Zitsas, while all other municipalities accounted for percentages in the $2-4.5 \%$ range. The lower the altitude and more-urbanised the area, the higher the percentage of the population employed. The highest rates of unemployment were found for the M. of Ano Pogoniou (22.7\%), Metsovou (20\%) and Zitsas (19.5\%) (Fig. 9B). Also, almost half of the unemployment at the time was "new" (Fig. 10B). When men and women are compared, the former are seen to experience higher levels of unemployment in all municipalities.

The study's main findings confirm the existence of certain regional inequalities between 
Education level

Higher education /MSc/PhD

Post secondary

Secondary

$\square$ Illiterate

Municipalities and Communities:

1. Aetomilitsas

2. Ag. Dimitriou

3. Anatolis

4. Ano Kalama

5. Ano Pogoniou

6. C. Zagoriou

8. Dervizianon

9. Distratou

10. Dodonis

11. E. Zagoriou

12. Egnatias

13. Ekalis

14. Evrumenon

15. Fourkas

16. loanniton

17. Kalariton

18. Kalpakiou

19. Katsanochorio

20. Konitsas

21. Lavdanis

22. Mastorochorio

24. Metsovou

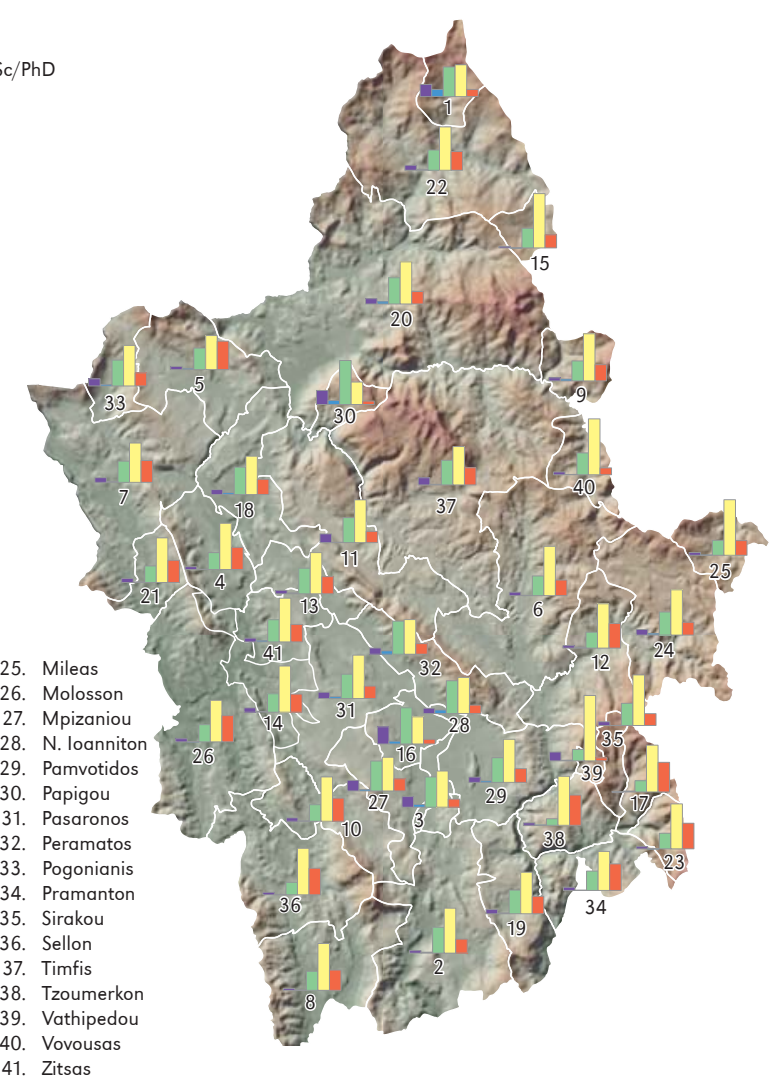

40. Vovousas

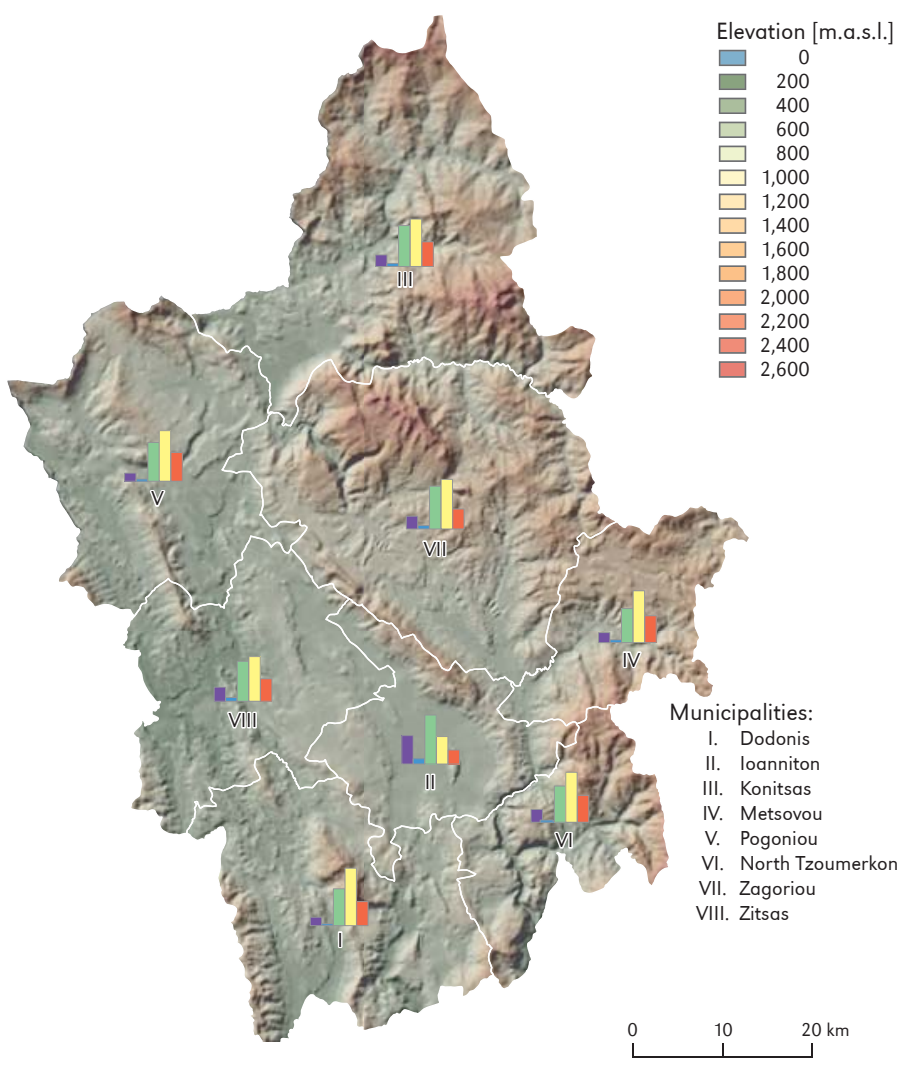

Figure 7. Proportional education level by municipality as of 2001 (A) and 2011 (B) 


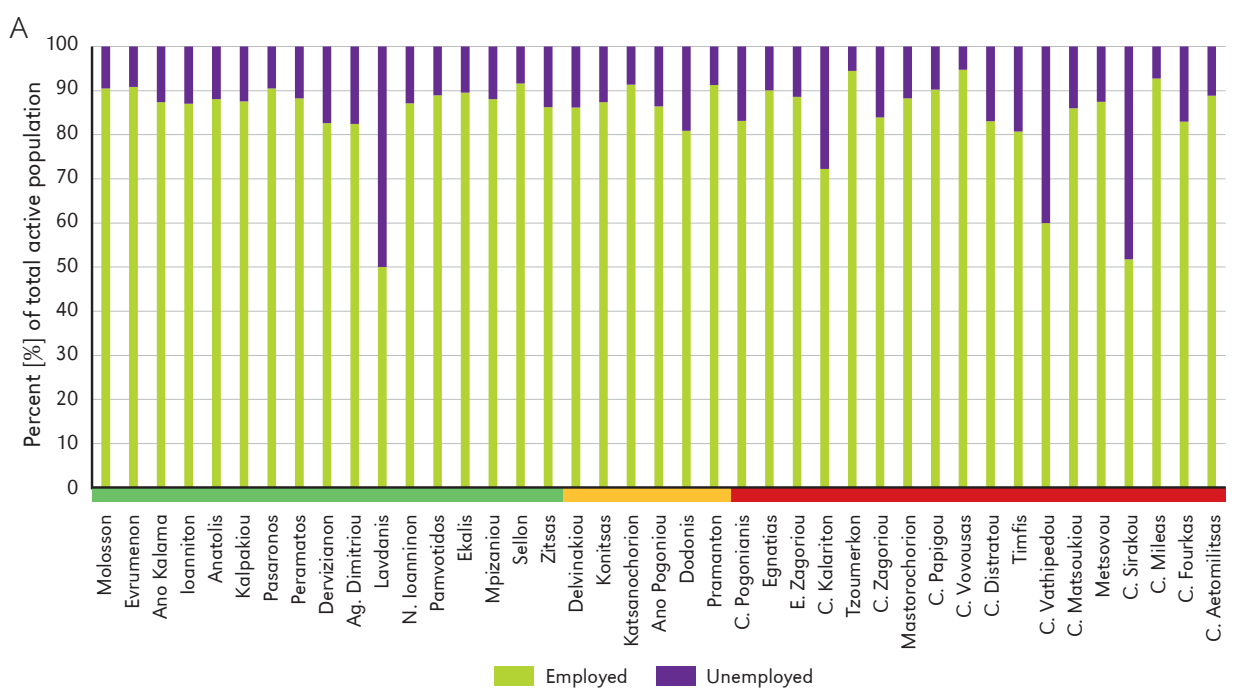

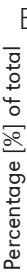

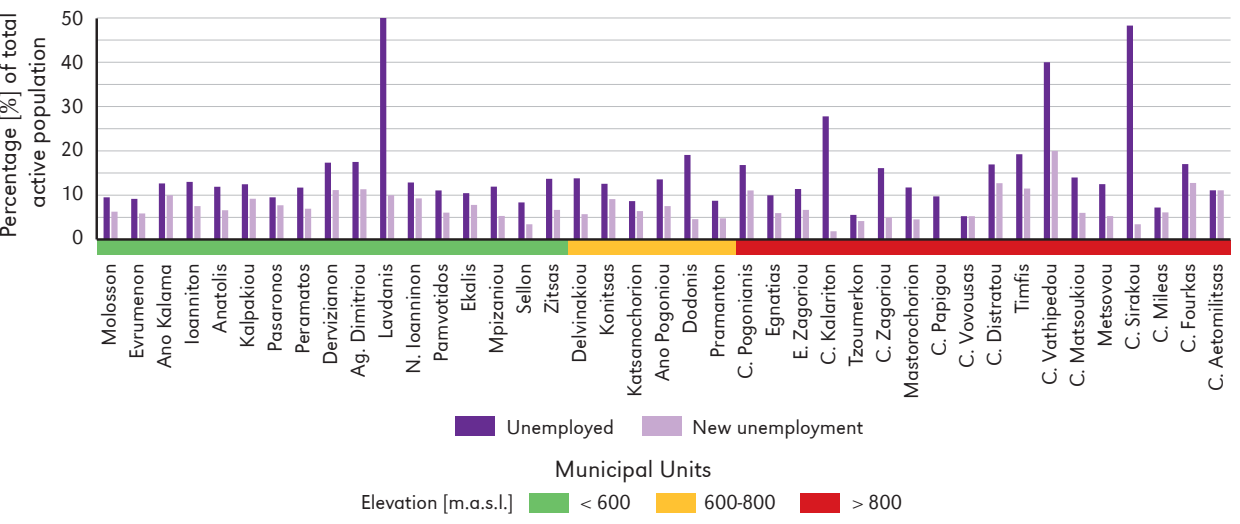

Figure 8. Employment rates as of 2001 (A) and new unemployment rates as of 2001 (B)

mountain areas and lowlands in Greece's Ionnina Regional Unit. Where elevations are greater, it is typical for depopulation and ageing to be intensified. Over half of the total population is concentrated at altitudes up to $500 \mathrm{~m}$ and in or around urban areas. In 2011, as very few mountain settlements were retaining a young population; either due to stable development, or as a reflection of a phenomenon whereby cities are left behind, first and foremost by those engaged in the tourism sector. However, there is no critical mass to this process as yet, with the vast majority of well-educated people still gathered in the lowlands. People who have stayed on in mountainous areas mostly have primary education, or no education at all. That finding reflects common lifestyles of the recent past, in addition to the lack of employment opportunities for the highly-skilled population in mountain regions. On average, rates of unemployment were higher in 2011 than 2001, as a consequence of Greece's economic crisis. Furthermore a mean rate of $13 \%$ (in 2001) concealed local rates in some mountainous areas that were as high as $40 \%$. In addition, higher altitudes witness more-marked disparities in unemployment rates between men and women, with men mostly experiencing unemployment. The vast 
Unemployment rate [\%]

- 20.0-100.0

$17.0-20.0$
$15.0-17.5$

$12.5-15.0$
$-7.0-12.5$

10.0-12.5

$7.5-10.0$
$5.0-7.5$

$\square \quad 2.5-5.0$

Unemployment by gender Share of

\section{Men Women}

Municipalities and Communities:

1. Aetomilitsas

2. Ag. Dimitriou

3. Anatolis

4. Ano Kalama

5. Ano Pogonio

6. C. Zagoriou

. Delvinakiou

8. Dervizianon
9. Distratou

9. Distratou

11. E. Zagorio

12. Egnatias

13. Ekalis

14. Evrumenon

15. Fourkas

16. loanniton

17. Kalariton

18. Kalpakiou

19. Katsanochorio

20. Konitsas

22. Mastorochorio

22. Mastorochor

23. Matsoukiou

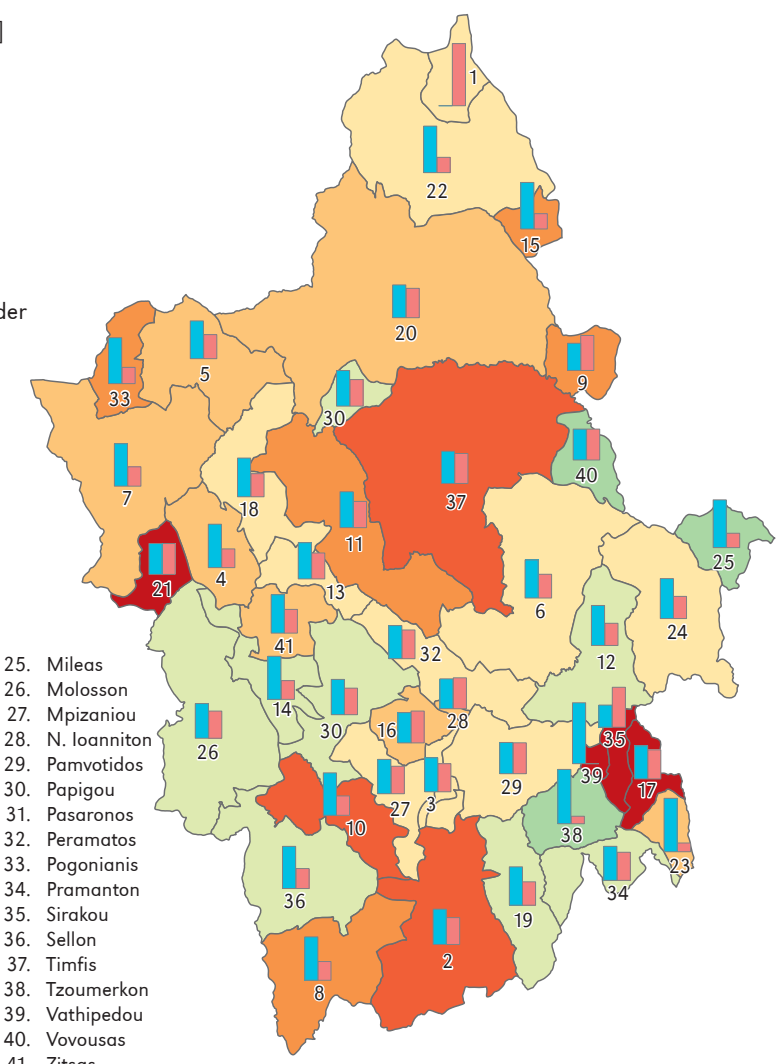

40. Vovousas

41. Zitsas

Figure 9. Percentage unemployment by municipality as of 2001 (A) and 2011 (B)

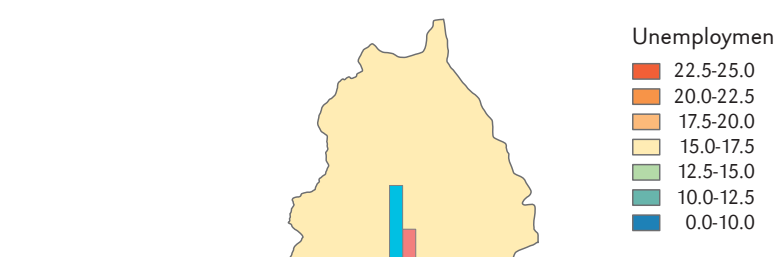

Unemployment by gende Share of

Men Women 


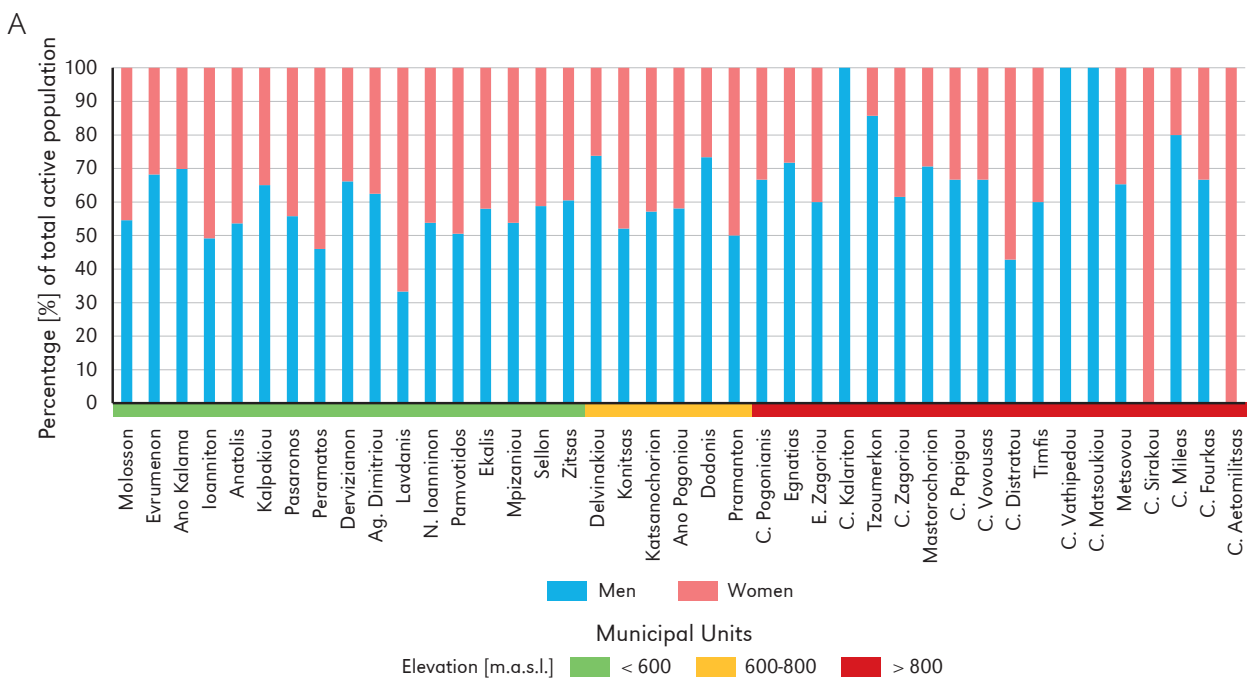

B

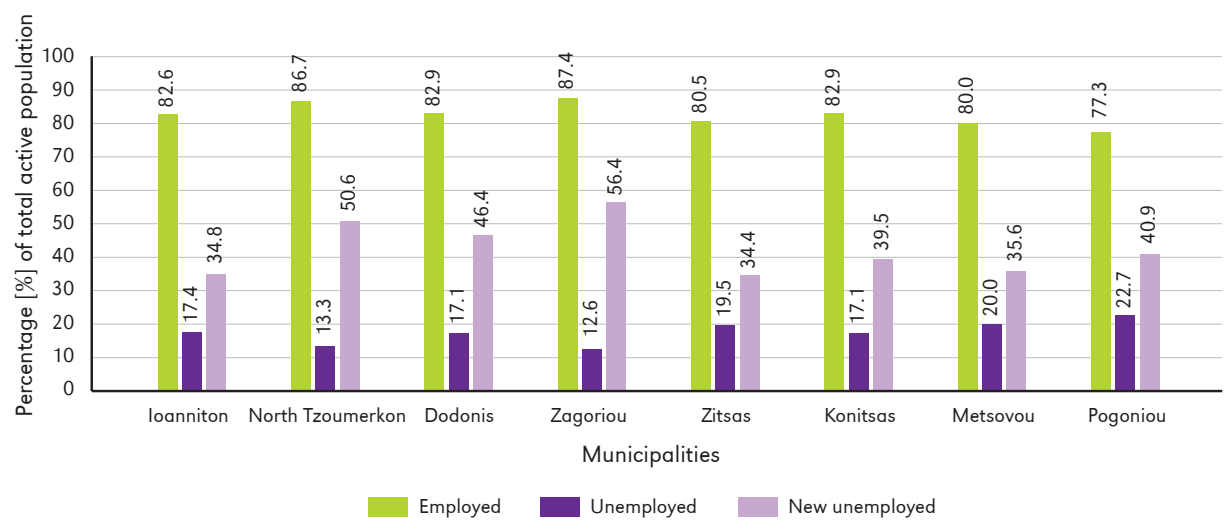

Figure 10. New unemployment as affecting men and women as of 2001 (A) and employment rates as of 2011 (B)

majority of the employed population is concentrated in lowlands and urban areas $(72 \%$ in 2011).

The economic crisis in Greece that was initiated in 2009 remained evident eleven years later, in all aspects of life throughout the country. Naturally, though, some areas proved to be worse affected, and areas underdeveloped at the outset were those suffering even more severely from the economic and social decline associated with the crisis. LessFavoured areas, and in particular the mountainous examples thereof (like the one featured in our case study) experienced decline of a more-severe nature. A main result of the economic crisis was the shrinkage of public funding for a variety of public-sector players, not least health and education, infrastructure and public services. Post-2010, austerity led to mergers and closures of schools all over the country. Part of that process involved a transfer of schoolchildren from higher to lower altitudes, and from mountainous to lowland areas. The same procedure affected healthcare and other public services (like Citizens' Service Centers, Revenue Services, etc.). Funding restrictions led to a postponement of the implementation of new infrastructure 
(above all roads) in many remote areas. As a result, there was a further intensification of the move out of mountainous areas into lowlands, with the fate of the former areas being ongoing and worsening decay. The shrinkage of private income likewise hit harder in mountain regions, inter alia because climatic conditions ensure higher energy costs there, as well as higher costs of production (in areas already facing severe restrictions in the farming sector). The fact that many mountainous regions rely on tourism for their incomes was yet a further factor ensuring a differential impact at a time of economic crisis. Income shrinkage led to a steady arresting of expenditure on the part of individuals, with luxury needs (like holidays) among the items of spending reduced most drastically. Entire mountain regions dependent on tourism (especially domestic) therefore saw major cuts in their annual profits. A case in point might be Metsovou, very much a tourist area, which experienced a halving in numbers of tourists in just two years of crisis (2008-2010) (Giannakopoulou, 2012).

Tourism is indeed a key driver of local development in many mountain regions, in Greece as in Europe more widely, and the relevant literature documents this clearly. Many Alpine regions owe their economic development to tourism activity. Less-Favoured Areas lagging behind where other development potential is concerned, could still tourism play a decisive role. However, if the phenomenon is to prove beneficial, it should be founded around a long-term strategic plan that takes account of each given area's specific features - and first and foremost in fact its carrying capacity. As tourism should be a vehicle for local recreation and the enhancement of the natural and cultural environment, what need enhancing are small-scale tourist activities close to localities already established, with this allowing for the promotion of local products and the supporting of a variety of supplementary activities. A policy aimed at a tourist "monoculture" would devour the resources of an area, ultimately leaving it in decline as opposed to making progress.
And indeed the recent crisis proved that that was so. Hence, a new policy focusing on real local needs and the enhancement of the quality of local communities through tourism should be the aim, in order that an integrated and robust development of mountain areas might be achieved.

\section{Mountain regions in the context of Cohesion Policy post-2020}

Research on mountain regions reveals how divergence is a common characteristic. Societies and cultures in such regions were shaped in natural environments more diverse than they might at first appear, with the result being very wide cultural diversity, even among areas in the same country. These circumstances ensure the impossibility of any integrated European policy common to all the continent's mountain regions. Nevertheless, mountain regions do share several similarities, with common problems and challenges foremost among them. It is not therefore surprising that mountain regions in a given country may share more similarities with mountain regions of a nearby country than with lowland parts at home. There is then a need to establish a general policy framework that at the same time provides for consideration being given to all the local specificities of mountain areas. To this end, Cohesion Policy may set overall aims and targets for the future development of mountain regions (Nordregio, 2004; EEA, 2010; Gløersen et al., 2016). Population trends, social and economic challenges such as the provision of educational facilities, and a reduction in unemployment (among the young in particular), should be among the high priorities of such a future policy.

The results of the research presented here reveal several inequalities between mountainous and lowland regions in the Regional Unit of loannina, in Epirus, Greece. As was documented in the previous section, mountain regions suffer from high rates of depopulation, population ageing, a relatively great concentration of the poorly- educated population and high rates of unemployment (even 
higher for men than for women). Our findings confirm general trends identified for most of Europe's mountainous regions. They likewise confirm a high level of divergence, with mountain regions differing much, not only from adjacent lowlands but also from other areas in the same category. This was very much reflected in findings comparing the lowland, urban region of the municipality of loannina with each of the mountainous municipalities above 600 and $800 \mathrm{~m}$.

The results of the study support a variety of conclusions to which consideration needs to be given if main priorities of a future development policy for the region are to be developed. To this end, the following would be topics for elaboration on various scales (if with the emphasis being on small-scale investigation):

- in the field of demography: population changes and out-migration patterns in a spatial-unit-level analysis of settlement; age structure of the permanent mountain-dwelling population; gender-oriented out-migration patterns; the dreams, expectations, needs, problems, etc. of the youthful population still present in mountains; and amenity migration patterns (with an emphasis on the circumstances in which people decide to abandon cities and restart their lives in mountains);

- in the field of education: the connection between out-migration flows and educational facilities available; educational preferences in mountain-dwelling populations in relation to real prospects/challenges/opportunities characterising these areas; the socioeconomic costs of the decline in basic school facilities in mountain regions; and paths to a permanent in-migration of educated people into mountain regions;

- in the field of employment: analysis of employment sectors in mountain regions; trends and opportunities; the socioeconomic stability of mountain regions; factors and challenges; and new technologies in the service of for innovative fields and means of employment.
In addition, updated data collection, mapping and analysis as regards empty buildings, the relocation of schools and health services, decline in public services, etc., should provide the necessary basis for targeted policy-making in support of the development of mountain regions. The application and use of smart technology could facilitate such procedures and act in support of policymakers.

All the above topics for elaborative smallscale investigation accord with the general main axes documented in the post-2020 policy for mountain areas, as mentioned by Gløersen et al. (2016). That is to say: (a) the preservation of decentralised-development settlement patterns; (b) the enhancement of collaboration between EU Cohesion Policy and small-scale, site-specific funding programmes implemented in the name of rural development; (c) the appreciation and consistent heeding of characteristics that make each mountain area specific; and hence recognition of the importance of divergence in such regions (the clear focus here is on smallerscale analysis, and on the implementation of policies suited to each different social and natural mountainous environment); (d) the promotion of economic activities according with, enhancing or redirecting already-established activity in each different mountain region (in tourism, services, agriculture, etc.). It is clear that a policy based around "one size fits all" will not work in mountain regions.

\section{Conclusions}

Regional disparities represent an ongoing issue at both the European and global levels. Given the existing social and economic gap that continued to be typical for Europe's regions, post-2020 EU Cohesion Policy has again been aimed at a reduction in disparities. As demography, education and employment are the three most important axes at which several policies are targeted, the work detailed here looked at demographic, educational and employment-related inequalities between mountain regions and lowlands in one of the most mountainous regions 
of Greece; i.e. the region of Epirus and its largest Regional Unit (RU), the RU of loannina. Statistical data for this area dating from 2001 and 2011 were presented, mapped and analysed.

Findings point to the existence of disparities of the above kinds in all three sectors. High rates of depopulation characterise the most-mountainous areas, while more than half of the total population is concentrated in places at altitudes up to $500 \mathrm{~m}$, and in or near urban areas. Only $9.5 \%$ of the studied population lives above $800 \mathrm{~m}$. Metsovou, a town with a long and important history is an exception, holding $2.5 \%$ of the overall population yet located at an altitude of $1150 \mathrm{~m}$. Young people are in the main abandoning mountain regions, with prevalent ageing of the population left behind. The population of elderly people is mostly concentrated at high altitude, while younger population (aged 18-55) are in the lowlands. Some of the most mountainous areas ( $>800 \mathrm{~m}$ ) are populated by the elderly to the tune of more than $60 \%$. Where education is concerned, the higher the altitude, the lower the level of educational attainment. High percentages of the overall population achieving only primary education or not educated at all reside at altitudes above $700 \mathrm{~m}$. The highly-educated and skilled population has in turn gathered in the lowlands and in urban centres, mainly, where there are altitudes of up to $600 \mathrm{~m}$. Unemployment seems to afflict both mountainous areas and lowlands, with an overall increase from 2001 to 2011 (mainly as a result of the crisis). While variation is present, regions at high altitude $(>800 \mathrm{~m}$ ) have rates of unemployment above $20 \%$. Equally, rates of new unemployment are very high (over 40\%) everywhere.

The findings here are similar to results obtained for many of Europe's mountain areas, as the relevant literature makes clear. Depopulation and ageing are key features of many mountain regions in Spain, Italy, France, Portugal and the Balkans. Similar trends are evident in many Carpathian regions (of Romania, Poland and Ukraine), as well as in the Caucasus area. It is mostly
Southern and Eastern Europe that show common demographic trends for their mountain regions. In addition, the phenomenon of young people abandoning the mountains for urban centres as noted for the RU of loannina does corresponds with results set out in the Euromontana (2012) report. It emerges that unemployment rates are generally higher in mountain areas than in the lowlands, with youth unemployment and new unemployment prevailing. In addition, the consequence of out-migration from mountains (and these areas' lack of basic services) is that people remaining in these areas mostly have primary education only. The highly-educated population has in turn gathered in the study area's lowlands and urban centres (in just the same way as it does in many other mountainous parts of Europe).

Given the need for main priorities of a post2020 Cohesion Policy to be formulated - and with special targeting of mountain regions - our survey is in a position to offer a useful general framework. More-specific analysis is called for at the level of even-smaller regions, given the existence of microscale disparities. Indicators targeted at the coarse level of large regions tend to ignore interregional inequalities entirely, even though it is precisely these exact inequalities that play a crucial role in the future development of mountain regions.

\section{Acknowledgments}

The authors would like to extend their warm thanks to the Editor and the Reviewers for their constructive remarks on several parts of the work, which resulted in a general enhancement of the paper.

Editors' note:

Unless otherwise stated, the sources of tables and figures are the authors', on the basis of their own research. 


\section{References}

Ariza, C., Maselli, D., Kohler, T. (2013). Mountains: Our life, our future. Progress and perspectives on sustainable mountain development from Rio 1992 to Rio 2012 and beyond. Bern, Switzerland: Swiss Agency for Development and Cooperation (SDC), Centre for Development and Environment (CDE).

Basiouka, A. (2011). The demographic identity of mountain regions of Greece. Postgraduate thesis. MSc programme "Environment and Development of Mountainous Areas". National Technical University of Athens. (in Greek).

Bauer, R., Fassmann, H. (2010). Demographic and migratory flows affecting European regions and cities. (DEMIFER), ESPON 2013 Programme, Deliverable 3 Typology of Regions. Retrieved from https://www.espon.eu/programme/projects/espon-2013/applied-research/demifer-demographic-andmigratory-flows-affecting [10 March 2020].

Castelein, A., Dinh, T.T.V., Mekouar, M.A., Villeneuve, A. (2006). Mountains and the law: Emerging trends. Rome: Food and Agriculture Organization of the United Nations.

Čede, P., Deissl, G., Löffler, R., Steinicke, E. (2018). The Eastern Austrian Alps - Their exceptional demographic status in the Alpine Region. European Countryside, 10(4), 634-651. https://doi.org/10.2478/euco-2018-0035

Cohesion Policy post 2020. Retrieved from https://vng.nl/files/vng/180913-presentatie-lewis-dijkstra_cohesion-policy-post-2020-utrecht.pdf [10 February 2020].

Collantes, F., Pinilla, V. (2004). Extreme depopulation in the Spanish rural mountain areas: A case study of Aragon in the nineteenth and twentieth centuries. Rural History, 15(2), 149-166. https://doi.org/10.1017/S0956793304001219

COM. (2010). Europe 2020. A strategy for smart, sustainable and inclusive growth. Retrieved from https://eur-lex.europa.eu/LexUriServ/LexUriServ.do?uri=COM:2010:2020:FIN:EN:PDF [15 February 2020].

CR 1057/2003. Regulation (EC) No 1059/2003 of the European Parliament and of the Council of 26 May 2003 on the establishment of a common classification of territorial units for statistics (NUTS).

CR 1257/1999. Council Regulation No 1257/1999 of 17 May 1999 on support for rural development from the European Agricultural Guidance and Guarantee Fund (EAGGF) and amending and repealing certain Regulations.

Darra, A., Kavouras, M., Tzelepis, N. (2003). A rational characterization and visualization of topographic relief into mountainous, semi-mountainous and plane terrain. Proceedings of 21st ICC, Durban.

Darra, A., Kavouras, M., Tzelepis, N. (2010). Characterization of Greek municipalities and sub-municipalities according to their topographic relief. Geographia Technica, Special Issue, 12-19.

Dax, T., Machold, I. (2019). New patterns of mobility, processes of integration and agency in Austrian rural areas. In G. Galera, I. Machold, M. Perlik, A. Membretti (Eds.), Alpine refugees: Immigration at the core of Europe (pp. 95-106). Newcastle upon Tyne: Cambridge Scholars Publishing.

Dimitriadis, E. (1997). The renaissance of the settlements in Greece during late Ottoman Empire. Archaeology and Arts, 65, 22-30. (in Greek)

Drăgan, M. (2010). Multi-scale analysis of the demographic evolution in the Apuseni Mountains between 1880 and 2008. Romanian Review of Regional Studies, 6(1), 57-66.

EEA. (2010). Europe's ecological backbone: Recognizing the true value of our mountains. Copenhagen, Denmark: European Environment Agency.

ELSTAT. (2001). Population Census 2001, De facto population, Permanent population. Hellenic Statistical Authority.

ELSTAT. (2011). Population Census 2011, De facto population, Permanent population. Hellenic Statistical Authority.

Euromontana. (2012). Strategies to increase the attractiveness of mountain areas: How to approach depopulation in an integrated manner? Final report on "integrated approach". Policies Against 
Depopulation in Mountain Areas (PADIMA). Retrieved from https://www.euromontana.org/wpcontent/uploads/2014/08/PADIMA_policy_guidlines_EN.df [10 February 2020].

Euromontana. (2013). Toward mountains 2020. Brussels: Euromontana.

Europe Strategy 2020. A European strategy for smart, sustainable and inclusive growth. Communication from the commission. Retrieved from http:/ec.europa.eu/eu2020/pdf/COMPLET\%20EN\%20BARROSO\%20\%20\%20007\%20-\%20Europe\%202020\%20-\%20EN\%20version.pdf [1 February 2020].

Eurostat. (2019). GDP per capita in 281 EU regions. Retrieved from https://ec.europa.eu/eurostat/documents/2995521/9618249/1-26022019-AP-EN.pdf/f765d183-c3d2-4e2f-9256-cc6665909c80 [20 May 2020].

Giannakopoulou, S. (2012). Evaluation of the vernacular architecture of mountain regions using Environmental Economics methods. (PhD thesis). National Technical University of Athens. (in Greek)

Gløersen, E., Price, M.F., Borec, A., Dax, T., Giordano, B. (2016). Cohesion in Mountainous Regions of the EU. Research for REGI Committee, European Parliament, Directorate-General for Internal Policies, Policies Department B: Structural and Cohesion Policies, Regional Development, IP/B/REGI/ IC/2015_175. Brussels, Belgium: European Parliament.

ICIMOD. (2010). Gender perspectives in mountain development: New challenges and innovative approaches. Periodical publication on sustainable mountain development. No 57 Summer, Kathmandu: International Center for Integrated Mountain Development.

Katsikas, C. (2018). Poverty drew 15,000 children out of school. Article in newspaper: TA NEA. Retrieved from https://www.tanea.gr/2008/10/31/greece/i-ftwxeia-ediwkse-15-000-paidia-apo-to-sxoleio/ [10 December 2019]. (in Greek)

Kebza, M., Nováček, A., Popjaková, D. (2019). Socio - Economic disparities in the Baltic States: Analytical comparison and categorization of the regions. Geographia Polonica, 92(3), 289-307. https://doi.org/ 10.7163/GPol.0150

Kohler, T., Elizbarashvili, N., Meladze, G., Svanadze, D., Meessen, H. (2017). The demo geographic crisis in Racha, Georgia: Depopulation in the Central Caucasus Mountains. Mountain Research and Development, 37(4), 415-424. https://doi.org/10.1659/MRD-JOURNAL-D-17-00064.1

Löffler, R., Beismann, M., Walder, J., Steinicke, E. (2014). New highlanders in traditional out-migration areas in the Alps. The example of the Friulian Alps. Journal of Alpine Research / Revue de géographie alpine, 102-3. https://doi.org/10.4000/rga.2546

Lung, M.S. (2019). Continuity and demographic cycling in the Romanian Carpathian space in the period 1930-2011. Analele Universității din Oradea, Seria Geografie, 29(1), 79-91. https://doi.org/10.30892/auog.291109-802

Matsouka, P., Adamakopoulos, T. (2008). The Greek mountains: Environment, habitation, mountain tourism. In Mountainous Space and Forests. Athens: Interdisciplinary Institute for Environmental Research. (in Greek)

Messerli, B., Ives, J.D. (Eds.). (1997). Mountains of the world: A global priority. Carnforth: Parthenon.

Mladenov, C., Ilieva, M. (2012). The depopulation of the Bulgarian villages. Bulletin of Geography, Socio-economic Series, 17, 99-107. http://dx.doi.org/10.2478/v10089-012-0010-8

Moss, L.A.G. (2008). Amenity-led change in rural towns and regions. Amenity Migration Planning Capacity Building Workshop 1, Castlegar, BC 09-11.

Moss, L.A.G. (Ed.). (2006). The amenity migrants: Seeking and sustaining mountains and their cultures. Wallingford, UK: CAB International.

New Cohesion Policy. Regional Development and Cohesion Policy beyond 2020: The New Framework at a glance. Retrieved from https://ec.europa.eu/regional_policy/en/2021_2027/ [1 January 2020].

Nordregio. (2004). Mountain areas in Europe. Analysis of mountain areas in EU Member States, acceding and other European countries. Final Report, Stockholm, Sweden: Nordregio. Retrieved from 
http://ec.europa.eu/regional_policy/sources/docgener/studies/pdf/montagne/mount1.pdf [15 December 2019].

Paizis, N., Fotopoulos, N. (n.d.). Study of the access system in tertiary education. Vol. 12. Scenarios of educational policy. Zones of educational priority. KANEP - GSEE. Retrieved from http://www.kanep-gsee.gr/sitefiles/files/tomos-12.pdf [1 December 2019]. (in Greek)

Panagiotopoulos, G., Kaliampakos, D. (2019). Accessibility and spatial inequalities in Greece. Applied Spatial Analysis and Policy, 12(3), 567-586. https://doi.org/10.1007/s12061-018-9256-8

Price, M.F., Dixon, B., Warren, C.R., Macpherson, R. (2002). Scotland's mountains: Key issues for their future management. Battleby: Scottish Natural Heritage.

Price, M.F. (2015). Mountains. A very short introduction. Oxford, USA: Oxford University Press.

Price, M.F. (2016). Mountains move up the European Agenda. Mountain Research and Development, 36(3), 376-379. https://doi.org/10.1659/MRD-JOURNAL-D-16-00100.1

Price, M.F., Jansky, L., latsenia, A.A. (Eds.). (2004a). Key issues for mountain areas. United Nations University Press.

Price, M.F., Lysenko, I., Gloersen, E. (2004b). Delineating Europe's mountains. Revue de Géographie Alpine Année, 92(2), 75-86. https://doi.org/10.3406/rga.2004.2294

Ruffini, F., Streifeneder, T., Eiselt, B. (2006). Implementing an international mountain convention - An approach for the delimitation of the Carpathian Convention area. Bolzano: European Accademy.

Terres, J-M., Toth, T., Wania, A., Hagyo, A., Koeble, R., Nisini, L. (2016). Updated guidelines for applying common criteria to identify agricultural areas with natural constraints. Luxembourg: Publications Office. https://doi.org/10.2788/130243

UNCED. (1992). United Nations Conference on Sustainable Development. Rio, 1992. Agenda 21.

UNEP-WCMC. (2002). Mountain watch. Environmental change and sustainable development in mountains. Retrieved from https://archive.org/details/mountainwatchenv02blyt [1 March 2020].

Website: http://www.epirus.gov.gr/portal/index.php/component/content/article/77-epikaira/296-paradosiakoi-oikismoi.html Widuto, A. (2019). Regional Inequalities in the EU. EPRS - European Parliamentary Research Service. Retrieved from http://www.europarl.europa.eu/RegData/etudes/BRIE/2019/637951/EPRS_BRI(2019)637951_EN.pdf [1 April 2020].

Zachou, C., Alipranti, L., Bavela, Z., Stamou, H., Stavropoulou, N., Zarotiadou, M. (2018). Greece. Education and Employment Commission (2017-2018). Retrieved from https://www.euw-hellas.gr/wp-content/uploads/2018/11/EUW-Report-2018-Education-and-Employment-Commission-pdf [15 April 2020]. 